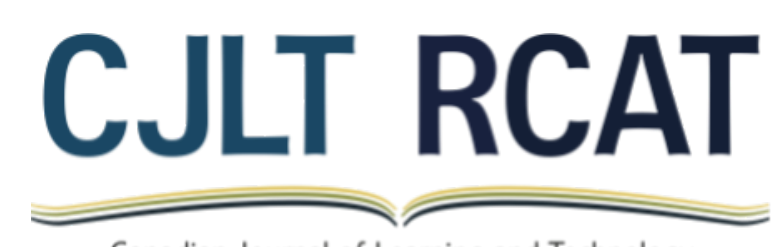

Canadian Journal of Learning and Technology

La Revue canadienne de l'apprentissage et de la technologie

Volume 47 (1)

Winter / Hiver 2021

\title{
Students' Learning Experience with a Flipped Introductory Organic Chemistry Course: A Course Designed for Non-Chemistry Majors
}

\section{L'expérience d'apprentissage des étudiants dans un cours inversé d'introduction à la chimie organique : Un cours conçu pour des étudiants sans spécialisation en chimie}

\author{
Horace Luong, University of Manitoba \\ Thomas Falkenberg, University of Manitoba \\ Mahdi Rahimian, Queen's University
}

\begin{abstract}
The use of flipped classrooms has been gaining popularity across various disciplines in higher education as a student-centered active learning strategy. In this study, an introductory organic chemistry course for students whose major is not in Chemistry was taught using a flipped classroom design, incorporating blended learning to deliver content, and using group work in the classroom. The learning experiences of the students enrolled in the course are discussed. Most of the students adjusted to the strategy and reported a sense of autonomy over their learning. Students also reported believing that most of the flipped classroom design components were a good use of their time in learning organic chemistry.
\end{abstract}

Keywords: organic chemistry; undergraduate; flipped classroom; blended learning; non-major

\section{Résumé}

L'utilisation de la classe inversée a gagné en popularité dans diverses disciplines de l'enseignement supérieur en tant que stratégie d'apprentissage actif centrée sur l'étudiant. Dans cette étude, un cours d'introduction à la chimie organique pour les étudiants dont la spécialisation n'est pas la chimie a été enseigné en utilisant une conception de classe inversée, en incorporant l'apprentissage hybride pour fournir le contenu et en utilisant le travail de groupe dans la salle de classe. Les expériences d'apprentissage de ces étudiants inscrits au cours sont discutées. La majorité des étudiants se sont adaptés à la stratégie et ont déclaré avoir un sentiment d'autonomie par rapport à leur apprentissage. Les étudiants ont également déclaré croire que la plupart des éléments de la conception 
de la classe inversée constituaient une bonne utilisation de leur temps pour apprendre la chimie organique.

Mots clés : chimie organique; premier cycle universitaire; classe inversée; apprentissage hybride; cours non spécialisé

\section{Introduction}

Over the last decade, and with the practical advancement of technology for the purpose of teaching and learning, the use of the flipped classroom as a form of blended learning has become more widespread in higher education (e.g., McNally et al., 2017; Hernández-Nanclares \& Pérez-Rodríguez, 2016; Reidsema, Kavanagh, Hadgraft, \& Smith, 2017). "In the flipped classroom, students are required to engage in or complete some form of preliminary learning online in preparation for a structurally aligned learning activity on campus with their instructors and peers" (Reidsema, Hadgraft, \& Kavanagh, 2017, p. 6). Learn-theoretical justifications for flipped classrooms are provided by social constructivism, which suggests that students learn best when they actively build on prior knowledge in a collaborative environment (Palincsar, 1998) and by cognitive load theory (Sweller, 1994), which suggests that students' learning is hindered when the working memory is overwhelmed. For instance, the former justifies a peer-learning aspect in the on-campus component of a flipped classroom, while the latter justifies delegating the exposure to the course material outside of class time and giving students the responsibility and flexibility to learn the material on their own (Seery, 2015).

Considering that these developments in higher education strategies are recent, it is no surprise that "research on the flipped classroom is still in its infancy" (Reidsema, Hadgraft, \& Kavanagh, 2017, p. 5). Our study adds this slowly emerging area of higher education research by inquiring into the experiences of the non-chemistry major students who attended a broad-topics first-year organic chemistry course in which used a flipped classroom design.

\section{Literature Review}

Over the last few years, there has been an increase in literature presenting the design, implementation, effectiveness, and students' attitudes of flipped classroom and blended learning as an active learning teaching method for general chemistry and organic chemistry in large and small class sizes (e.g., Bernard et al., 2017; Christiansen, 2014; Eichler \& Peeples, 2016; Fautch, 2015; Flynn, 2015; He et al., 2016; Hibbard et al., 2016; Lenczewski, 2016; Mooring, et al., 2016; Naibert et al., 2020; Reid, 2016; Rossi, 2015; Ryan \& Reid, 2016; Seery, 2015; Shattuck, 2016; Smith, 2013; Weaver \& Sturtevant, 2015).

There are many ways to design a course using the flipped classroom model, although the underlying structure is the same - delegate content learning to outside of class time while using in-class time to apply and problem solve with the content (Christiansen, 2014; Fautch, 2015; Seery, 2015). Instructors who adopt a flipped classroom model may assign readings or provide online videos for 
students to watch to learn the content. The integration of online experiences in the delivery of content into a course with a face-to-face component is known as blended learning (also known as hybrid learning) (Driscoll, 2002). For instance, Eichler \& Peeples (2016) provided videos for students to watch for learning the content which was supplemented with online tutorials and a quiz to help encourage active learning during the pre-lecture period.

As a method of maximizing teaching efficiency, a "just-in-time teaching" (JiTT) strategy was used in our study. Developed about 20 years ago, JiTT is a strategy where students prepare for class time by reading materials or watching online content and then completing online assignments before class time. The instructor uses classroom activities with a focus towards resolving the weaknesses in the online assignments (Novak, 2011; Slunt \& Giancarlo, 2004). The usefulness of active online learning prior to class time was recently demonstrated by Casselman et al. (2020) who studied the effect of online learning in a flipped-classroom model that contributed to skills-based learning as much or more than collaborative (group-based learning) learning.

Research in the use of class time has included instructors helping the students engage in productive collaborative practices (Chase et al., 2013; Lyon \& Lagowski, 2008), using small group discussions (Oliver-Hoyo \& Allen, 2005), incorporating problem solving activities (Hibbard et al., 2016), and delivering mini-lectures to address student misconceptions and build content knowledge before class activities (Kirik \& Boz, 2012; Ryan \& Reid, 2016).

Motivations for instructing a class using the flipped classroom framework include the following:

- extending course accessibility/flexibility and convenience (Aspden \& Helm, 2006; Cooner, 2010; Garrison \& Vaughan, 2013; Smyth et al., 2012),

- delivering content via a medium that appeals to the current generation of students (Donnelly, 2010; Lancaster et al., 2012),

- promoting student autonomy (Ginns \& Ellis, 2009; Holley \& Oliver, 2010; Owston et al., 2013; Shea \& Bidjerano, 2010),

- fostering critical thinking, reflection, and problem solving (Cooner, 2010; Lyons \& Evans, 2013; Snodgrass, 2011),

- $\quad$ increasing student satisfaction with learning (Lyons \& Evans, 2013; Woltering et al., 2009; Wu et al., 2010),

- improving learning outcomes and student's performance (Freeman et al., 2014; Hwang \& Arbaugh, 2009; Lancaster, 2013; Lopez-Perez, et al., 2011; Warfa, 2016), and

- improving collaboration skills (Aspden \& Helm, 2006; Hwang \& Arbaugh, 2009; Shea \& Bidjerano, 2010; Snodin, 2013).

There are conflicting results presented in recent literature on the student attitudes towards a flipped chemistry classroom. However, papers presenting the positive effects on students (Chase et al., 2013; Eichler \& Peeples, 2016; Hemraj-Benny \& Beckford, 2014; Hibbard et al., 2016; Lenczewski, 2016; Mooring et al., 2016; Oliver-Hoyo \& Allen, 2005; Ryan \& Reid, 2016; Trogden, 2015; Weaver \& Sturtevant, 2015) either in performance and/or student attitudes with respect to learning progress, 
confidence, and motivation outnumber the papers presenting the negative attitudes or learning experiences (He et al., 2016) or demonstrating no significant improvement in student performance compared to those taught by traditional lectures (Christiansen, 2014; Rein \& Brookes, 2015). The studies that found no significant improvement, however, have found that there may be improvements to student confidence and enthusiasm (Chase et al., 2013; Hemraj-Benny \& Beckford, 2014; Oliver-Hoyo \& Allen, 2005; Rau et al., 2017).

\section{Study Design}

\section{Research Purpose and Questions}

The purpose of this study is to contribute to the understanding of the potential benefits of using a flipped classroom design in higher education with a technology-based out-of-class (blended learning) component. Specifically, the study uniquely focused on students' perceived experiences with the use of a flipped classroom design (described in the next section) in a first year broad-topics organic chemistry course designed for students who are non-chemistry majors.

Most studies on flipped classroom designs in chemistry education have been focused on students in general or organic chemistry courses where they are enrolled as chemistry majors. (Eichler \& Peeples, 2016; Fautch, 2015; Flynn, 2015; He et al., 2016; Hibbard et al., 2016; Mooring et al., 2016; Rossi, 2015; Seery, 2015; Shattuck, 2016; Smith, 2013; Weaver \& Sturtevant, 2015). These chemistry courses typically cover a depth and breadth of topics for students to continue into more advanced chemistry courses.

Many institutions offer general and/or organic chemistry service courses targeted towards students who are not majoring in chemistry or natural sciences (e.g., students in humanities, nursing, agriculture, human nutritional sciences, engineering, etc.) but require a broad survey of topics relevant to their field and may be at the expense of topic depth. It is important to study this population as students who enrol in these non-major chemistry courses may have different motivations, goals, and educational strengths and backgrounds (prerequisite courses) from those in a major-oriented chemistry course. Studies involving students in non-major orientated organic chemistry courses are limited in number and most of those studies use a small sample size (Christiansen, 2014; Rein \& Brookes, 2015).

This study undertaken at a large Canadian university with non-chemistry major students had the following two research questions:

1. What are students' perceptions of their experiences with the flipped and blended classroom design?

2. What are students' perceptions of their experiences with specific course components?

\section{Course Design}

CHEM 1320 is an introductory course to organic chemistry that is offered as a service course only and serves as an alternate prerequisite for an introductory biochemistry course. Typically, CHEM 1320 has been offered as a single section (average enrolment of over 100 students) in a 50-minute class 
time slot, meeting three times per week. To accommodate the flipped classroom design, the course was offered once a week with a 110-minute class. Overall, in-class time was reduced by about 40 minutes per week to account for the out-of-class activities time. The sum of the 110-minute in-class time and 40-minute out-of-class time per week equated to the 150-minute/week contact time in the traditional lecture format. In addition - and at the expense of increasing the instructor's student contact hours by about $30 \%$ - the course was divided into two sections to provide registration flexibility for students and for the university in finding an appropriate classroom; also, enrolment was reduced to 60 students per section.

The grade assessment for the course was divided into online homework (5\%), laboratory (15\%), take-home midterm (10\%), and final examination (70\%). The questions on the midterm and final examination were closely structured to align with the online homework, instructor-devised questions from class, and textbook problems.

In accordance with the general flipped classroom design, the course included an out-of-class preliminary learning opportunity for students and in-class activities that made use of the preliminary learning opportunity. For out-of-class activities, students were asked to complete the following four activities prior to class time each week, which were reviewed by the course instructor prior to class:

- read assigned textbook pages,

- watch an online screencast lecture video,

- work on the textbook problems, and

- complete the online homework assignment administered through Cengage's OWLv2.

Students were allocated marks for completing the assignment (5\% total of course grade); answer accuracy was not assessed. The screencasts were created using Camtasia Studio to edit annotated PowerPoint slides and audio recording. The screencasts were published on YouTube for its powerful analytics to track viewing behaviour, which can be used to infer study habits and learning behaviour. The links to the screencasts were made available to the students through the learning management system. The in-class activities consisted of three activities presented in the following order: going over common problems in the online homework (about 30 minutes), student group work solving instructorcreated problems (about 60 minutes), and instructor-based preview lecture on the next module (about 20 minutes).

\section{Methodology}

\section{Participants}

Study participants were recruited from the students in the two sections of CHEM 1320 in the 2017 winter term. The course was offered in the flipped classroom format over a 12-week period. Sixty-eight percent of the study participants were in the course because it was required for their major (program requirement) and 27\% were in the course because it was a course required by their faculty (faculty requirement). Thirty-three percent of the students were majoring in agroecology, agronomy, animal systems or plant biotechnology; $37 \%$ of the students were majoring in food science, human 
nutritional science, or nutrition option; $21 \%$ were students majoring in science or undeclared; $7 \%$ were students in the dental hygiene program; and 2\% were students in an engineering program. The class was comprised of approximately 30\% first year, 30\% second year, 30\% third year, and 10\% fourth year and beyond students. Participants were not asked for their gender identity. Student participation in the different surveys used for this study was between $63 \%$ and $65 \%$ of all students in both sections of the course studied (total course enrolment $=112$ ). About $19 \%$ of the study participants had prior experience working in one course offered in both flipped classroom and blended learning and about $62 \%$ had at least one course where online video lectures were available. There were no significant changes in enrolment during the study (by the end of term, there was only a 3\% decrease in enrolment compared to the first day of class). In the instructor's experience, this was an unusually small decrease in enrolment compared to other terms and therefore may have been the result of the University's new policy on limiting access to registration for students who voluntarily withdraw from a course.

\section{Instructor}

The course instructor is an experienced organic chemist, instructor in the Department of Chemistry, and has taught the CHEM 1320 course seven times between 2009 winter and 2015 winter in a traditional lecture format with no prior experience teaching in a blended learning, flipped classroom format.

\section{Data Collection and Analysis}

To respond to our research questions, three surveys were developed and administered with Likert-type and open-ended questions. Survey 0 was administered on the first day of class to primarily collect information on the student population, Survey 1 was administered the week after the midterm due date, and Survey 2 was administered the last day of class (end of term). As well, data from the student course evaluations on educational quality (teaching effectiveness survey) conducted on the penultimate week of class were also used (Survey 3 ). The survey questions are described in the findings section below.

The descriptive statistical tools, median and frequency distribution, were used for the analysis of the survey data.

\section{Findings}

The presentation of the study's findings is divided into two parts. Each part responds to one of the study's two research questions. In the findings, we will speak of "the students" which means the students in the course who participated in the study.

\section{Students' Experiences with the Flipped Classroom Design Overall}

The data for the first research question - how students judge their experience with the flipped classroom design overall - were primarily drawn from three questions from Survey 1 and 2. Table 1 presents students' responses to the three questions. 


\section{Table 1}

Students' Judgment of their Experience with the Flipped Classroom Design Overall

\begin{tabular}{|c|c|c|c|c|c|c|c|c|}
\hline Questions & $\begin{array}{l}\text { Questionnaire } \\
\text { Conduct } \\
\text { Period }\end{array}$ & $\begin{array}{l}\mathrm{N}, \% \\
\text { of } \\
\text { class }\end{array}$ & Median & $\begin{array}{c}1 \\
\text { (Strongly } \\
\text { Disagree) }\end{array}$ & 2 & 3 & 4 & $\begin{array}{l}\quad 5 \\
\text { (Strongly } \\
\text { Agree) }\end{array}$ \\
\hline \multirow{2}{*}{$\begin{array}{l}\text { You have adjusted to the } \\
\text { flipped classroom learning } \\
\text { approach. }\end{array}$} & Post midterm & $\begin{array}{c}72 \\
64 \%\end{array}$ & Agree & 0 & 12 & 19 & 35 & 6 \\
\hline & End of term & $\begin{array}{l}72 \\
64 \%\end{array}$ & Agree & 7 & 17 & 9 & 28 & 11 \\
\hline $\begin{array}{l}\text { Flipped classroom teaching } \\
\text { approach made you feel } \\
\text { more comfortable asking } \\
\text { questions or initiating } \\
\text { discussions compared to the } \\
\text { traditional lecture style } \\
\text { teaching approach. }\end{array}$ & Post midterm & $\begin{array}{c}70 \\
63 \%\end{array}$ & Agree & 3 & 9 & 14 & 27 & 17 \\
\hline $\begin{array}{l}\text { You feel more in control of } \\
\text { your learning in this flipped }\end{array}$ & Post midterm & $\begin{array}{l}73 \\
65 \%\end{array}$ & Agree & 4 & 10 & 18 & 33 & 8 \\
\hline $\begin{array}{l}\text { classroom compared to a } \\
\text { traditional lecture style } \\
\text { teaching approach. }\end{array}$ & End of term & $\begin{array}{l}72 \\
64 \%\end{array}$ & Agree & 7 & 16 & 7 & 31 & 11 \\
\hline
\end{tabular}

In response to the first questions, slightly more than half agreed or strongly agreed that they had adjusted to the flipped classroom learning approach, and they felt more in control of their learning in the flipped classroom compared to a traditional lecture style teaching approach. These numbers stayed consistent from the middle to the end of the course. At the end of the course, about one third of the students said they did not adjust to the flipped classroom learning approach, and they did not feel in control of their learning compared to a traditional lecture style teaching approach. The number of students with these sentiments had doubled and increased by about three quarters, respectively, from the midway mark to the end of the course. At the midway mark, almost two-thirds of students judged that, compared to the traditional lecture style teaching approach, the flipped classroom approach made them feel more comfortable asking questions or initiating discussions. Only $17 \%$ disagreed or strongly disagreed with their peers' judgment. It is noteworthy that the Table 1 questions were presented for the "flipped classroom design"; however, since there was no separation of "blended learning" and "flipped classroom" in the survey questions, it would be appropriate to consider "flipped classroom design" to refer to a flipped classroom design with a blended learning component.

Students' overall judgment of their experience with the flipped classroom design must be viewed in the context of workload and level of difficulty relative to other courses. Table 2 addresses these aspects of students' experiences with the course. 


\section{Table 2}

Students' Judgment Collected from Surveys on the Penultimate Class of the Amount of Work and the Level of Difficulty of the Course Overall

\begin{tabular}{|c|c|c|c|c|c|c|c|}
\hline Question & $\begin{array}{l}\mathrm{N}, \% \\
\text { of } \\
\text { class }\end{array}$ & Median & $\begin{array}{l}\text { Very } \\
\text { Light }\end{array}$ & Light & Average & Heavy & $\begin{array}{l}\text { Very } \\
\text { Heavy }\end{array}$ \\
\hline $\begin{array}{l}\text { Course workload, relative to } \\
\text { other courses was }\end{array}$ & $\begin{array}{l}72 \\
64 \%\end{array}$ & Heavy & 0 & 1 & 14 & 26 & 31 \\
\hline $\begin{array}{l}\text { Hours per week required } \\
\text { outside of class }\end{array}$ & $\begin{array}{l}71 \\
63 \%\end{array}$ & Heavy & 1 & 7 & 25 & 25 & 13 \\
\hline Question & $\begin{array}{l}\mathrm{N}, \% \\
\text { of } \\
\text { class }\end{array}$ & Median & $\begin{array}{l}\text { Very } \\
\text { Easy }\end{array}$ & Easy & Average & Difficult & $\begin{array}{l}\text { Very } \\
\text { Difficult }\end{array}$ \\
\hline $\begin{array}{l}\text { Course difficulty, relative to } \\
\text { other courses }\end{array}$ & $\begin{array}{l}73 \\
65 \%\end{array}$ & $\begin{array}{l}\text { Very } \\
\text { Difficult }\end{array}$ & 0 & 0 & 0 & 19 & 54 \\
\hline Question & $\begin{array}{l}\mathrm{N}, \% \\
\text { of } \\
\text { class }\end{array}$ & Median & $\begin{array}{l}\text { Too } \\
\text { Slow }\end{array}$ & Slow & $\begin{array}{l}\text { About } \\
\text { Right }\end{array}$ & Fast & Too Fast \\
\hline Course pace was & $\begin{array}{l}73 \\
65 \%\end{array}$ & Fast & 0 & 0 & 28 & 38 & 7 \\
\hline
\end{tabular}

When compared to other courses, about $80 \%$ of students considered the course workload heavy or very heavy and $100 \%$ of students considered the course difficult or very difficult. Considering that $46 \%$ of the students did not spend more than an average number of hours on the course outside of class time, for many of the students who found the workload (very) heavy and the course content (very) difficult, this did not translate into more hours spent on the course outside of class time.

In addition to the findings that almost all students judged the course workload as (very) heavy and its content as (very) difficult, about 6 in 10 students considered the course pace fast or too fast. Overall, this suggests that the non-chemistry major students found the course content very demanding. While content is always experienced in the form in which the content appears to the learner, we suggest that the data presented in Table 2 indicate challenges that non-chemistry majors face in learning content of an introductory organic chemistry course regardless of the course design and, thus, students' experiences with the specific course design under investigation here - i.e., the flipped classroom design - have to be interpreted in light of these design-independent challenges.

To help with the future planning of the course delivery, the survey asked students' views on their preferred schedule for the course if offered with a flipped classroom design (Table 3). Table 3 shows that almost all students preferred between 120 and 150 minutes of total instruction per week. However, in terms of how those minutes are to be distributed, 6 out of 10 students prefer to have the class time not in one block per week (as was the schedule of the course delivery for this study), but rather in a split of two (28\%) or three (28\%) sessions per week. Most of the students clearly preferred 
spreading the in-class learning over two or three sessions per week rather than "cram" all the material into one in-class session.

\section{Table 3}

Students' Judgment Collected from Surveys at the End of Term on Different Course Schedule Schemes ( $N$ end of term $=72,64 \%)$

\begin{tabular}{llllll}
\hline Question & $\begin{array}{l}\text { One 2 hr } \\
\text { class/week }\end{array}$ & $\begin{array}{l}\text { One }>2 \mathrm{hr} \\
\text { class/week }\end{array}$ & $\begin{array}{l}\text { One }<2 \mathrm{hr} \\
\text { class/week }\end{array}$ & $\begin{array}{l}\text { Three 50- } \\
\text { minute } \\
\text { classes/week }\end{array}$ & $\begin{array}{l}\text { Two 75- } \\
\text { minute } \\
\text { classes/week }\end{array}$ \\
\hline $\begin{array}{l}\text { For the flipped classroom teaching } \\
\text { approach, which schedule format } \\
\text { would you prefer? }\end{array}$ & $33 \%$ & $10 \%$ & $1 \%$ & $28 \%$ & $28 \%$ \\
\hline
\end{tabular}

\section{Students' Judgment of their Experience with the Different Design Components}

The findings for the second research question - the question of how students judged their experience with the different design components - are divided into two parts. In the first part, we asked students to judge their experience with the design components and in the second part, we asked students to judge their engagement with the design components. Table 4 shows students' responses to five questions relating to the first part.

Overall, for each design component, between $50 \%$ and $75 \%$ of students found the respective component a good use of their time, valuable or effective for their learning of organic chemistry, while between $15 \%$ and $30 \%$ of students found the respective components not a good use of their time, and not valuable or effective for their learning of organic chemistry. More specifically, students' responses to the four components fell into two groups. The online homework and the video lectures with problem solving assignments both were found helpful by a significantly fewer number of students than was the case for the other two components (about 50\% compared to about 33-75\%) and had a much higher number of students who found both less helpful to their learning than was the case for the other two components (about 25-30\% compared to about 10-15\%, respectively). The intent for using an online homework system was to give students an opportunity to practice questions and receive feedback as well as provide the instructor with a litmus test on the students' understanding of the material (any deficiencies could be covered in the review lectures). The choice of online homework systems was based on the textbook used since their information readily complemented each other. The instructor reported that the students initially had some difficulty understanding the questions and/or how to input an answer, and these barriers may have been resolved for some students by the end of the term. 


\section{Table 4}

Students' Judgment of their Experience with the Different Design Components

\begin{tabular}{|c|c|c|c|c|c|c|c|c|}
\hline Questions & $\begin{array}{l}\text { Questionnaire } \\
\text { Conduct Period }\end{array}$ & $\begin{array}{c}\mathrm{N}, \% \text { of } \\
\text { class }\end{array}$ & Median & $\begin{array}{c}1 \\
\text { (Strongly } \\
\text { disagree) }\end{array}$ & 2 & 3 & 4 & $\begin{array}{c}5 \\
\text { (Strongly } \\
\text { agree) }\end{array}$ \\
\hline \multirow{2}{*}{$\begin{array}{l}\text { You value the opportunity } \\
\text { to work with other } \\
\text { students in groups. }\end{array}$} & Post Midterm & $\begin{array}{l}71 \\
63 \%\end{array}$ & Agree & 0 & 8 & 12 & 35 & 16 \\
\hline & End of Term & $\begin{array}{l}70 \\
63 \%\end{array}$ & Agree & 4 & 8 & 12 & 30 & 16 \\
\hline \multirow{2}{*}{$\begin{array}{l}\text { In-class group work was a } \\
\text { good use of your time for } \\
\text { learning organic chemistry. }\end{array}$} & Post Midterm & $\begin{array}{c}72 \\
64 \%\end{array}$ & Agree & 2 & 8 & 11 & 32 & 19 \\
\hline & End of Term & $\begin{array}{l}72 \\
64 \%\end{array}$ & Agree & 8 & 7 & 18 & 31 & 8 \\
\hline \multirow{2}{*}{$\begin{array}{l}\text { Doing the online } \\
\text { homework was a good use } \\
\text { of your time for learning } \\
\text { organic chemistry. }\end{array}$} & Post midterm & $\begin{array}{l}72 \\
64 \%\end{array}$ & Agree & 8 & 11 & 19 & 30 & 4 \\
\hline & End of term & $\begin{array}{c}72 \\
64 \%\end{array}$ & Agree & 7 & 10 & 17 & 33 & 5 \\
\hline \multirow{2}{*}{$\begin{array}{l}\text { Watching video lectures } \\
\text { and problem solving were } \\
\text { more effective in your } \\
\text { learning compared to } \\
\text { traditional lecture style } \\
\text { teaching approach. }\end{array}$} & Post midterm & $\begin{array}{l}72 \\
64 \%\end{array}$ & Neutral & 7 & 8 & 22 & 22 & 13 \\
\hline & End of term & $\begin{array}{c}72 \\
64 \%\end{array}$ & Agree & 8 & 13 & 12 & 30 & 9 \\
\hline \multirow{2}{*}{$\begin{array}{l}\text { The introduction given by } \\
\text { the lecturer at the } \\
\text { beginning of each class } \\
\text { and/or the preview at the } \\
\text { end of each class were a } \\
\text { good use of time for } \\
\text { learning organic chemistry. }\end{array}$} & Post Midterm & $\begin{array}{l}72 \\
64 \%\end{array}$ & Agree & 2 & 4 & 11 & 32 & 23 \\
\hline & End of Term & $\begin{array}{c}72 \\
64 \%\end{array}$ & Agree & 1 & 6 & 15 & 37 & 13 \\
\hline
\end{tabular}

The accompanying review and preview lectures had the strongest affirmation by students with $76 \%$ (midway) and 69\% (end of course), respectively, among the design components. Linking these findings with the results to the first research question, the students' positive experience with the review and preview lecture design components is not an indication that students prefer the traditional lecturestyle design of teaching over the flipped classroom design experience. Rather, the findings should be understood to suggest that the specific features of the review and preview lectures complemented other components of the design. The lectures were characterized as being relatively brief (up to 20 minutes) and they either reviewed material that students were already familiar with (review lectures) through 
their prior engagement with other design components (video and online homework) or the lecture provided a general overview of material to be learned (preview lectures), where the main engagement with the material was pending (video, online homework, review lectures, and group work on problems). In this context the lecture was not the main form of engagement with new material, as is the case in traditional lecture-style design of teaching in higher education.

The findings on how students engaged with the different design components are drawn from student responses to the seven questions listed in Table 5.

\section{Table 5}

Students' Judgment of their Experiences with the Way the Different Components Engaged them during Class

\begin{tabular}{|c|c|c|c|c|c|c|c|c|}
\hline Questions & $\begin{array}{l}\text { Questionnaire } \\
\text { Conduct Period }\end{array}$ & $\begin{array}{l}\mathrm{N}, \% \text { of } \\
\text { class }\end{array}$ & Median & 1 & 2 & 3 & 4 & 5 \\
\hline $\begin{array}{l}\text { Students were encouraged to participate } \\
\text { in class discussions } \\
\text { ( } 1 \text { = Strongly disagree, } 5 \text { = Strongly agree) }\end{array}$ & $\begin{array}{l}\text { Penultimate } \\
\text { class }\end{array}$ & $\begin{array}{c}73 \\
65 \%\end{array}$ & Agree & 0 & 2 & 6 & 35 & 30 \\
\hline $\begin{array}{l}\text { Students were invited to share their ideas } \\
\text { and knowledge } \\
\text { ( } 1 \text { = Strongly disagree, } 5 \text { = Strongly agree) }\end{array}$ & $\begin{array}{l}\text { Penultimate } \\
\text { class }\end{array}$ & $\begin{array}{l}72 \\
64 \%\end{array}$ & Agree & 0 & 1 & 13 & 37 & 21 \\
\hline $\begin{array}{l}\text { Students were encouraged to ask } \\
\text { questions and were given meaningful } \\
\text { answers } \\
\text { (1 = Strongly disagree, } 5=\text { Strongly agree) }\end{array}$ & $\begin{array}{l}\text { Penultimate } \\
\text { class }\end{array}$ & $\begin{array}{l}73 \\
65 \%\end{array}$ & Agree & 1 & 2 & 5 & 34 & 31 \\
\hline $\begin{array}{l}\text { Students were encouraged to express } \\
\text { their own ideas and/or question the } \\
\text { instructor } \\
\text { (1 = Strongly disagree, } 5 \text { = Strongly agree) }\end{array}$ & $\begin{array}{l}\text { Penultimate } \\
\text { class }\end{array}$ & $\begin{array}{l}72 \\
64 \%\end{array}$ & Agree & 0 & 3 & 9 & 38 & 22 \\
\hline $\begin{array}{l}\text { You engaged actively in the assigned } \\
\text { group work. }\end{array}$ & Post Midterm & $\begin{array}{l}72 \\
64 \%\end{array}$ & Agree & 0 & 3 & 13 & 37 & 19 \\
\hline (1 = Strongly disagree, 5 = Strongly agree) & End of Term & $\begin{array}{l}72 \\
64 \%\end{array}$ & Agree & 2 & 4 & 19 & 28 & 19 \\
\hline $\begin{array}{l}\text { On average, the problems discussed in } \\
\text { class were } \\
(1=\text { Too easy, } 3=\text { about right, } 5=\text { Too } \\
\text { hard })\end{array}$ & End of Term & $\begin{array}{l}70 \\
63 \%\end{array}$ & Harder & 1 & 0 & 30 & 30 & 9 \\
\hline $\begin{array}{l}\text { Approximately what percentage of the } \\
\text { assigned homework questions from the } \\
\text { textbook were completed? } \\
\text { ( } 1=\text { none or almost none, } 2=\text { some, } \\
3=\text { about half, } 4=\text { most, } 5=\text { all or almost all) }\end{array}$ & End of Term & $\begin{array}{l}72 \\
64 \%\end{array}$ & Some & 30 & 28 & 7 & 6 & 1 \\
\hline
\end{tabular}


In the judgment of about 8 out of 10 students, their experience with the course design suggested high quality learning experiences in accordance with university course evaluation standards in terms of opportunities for students to participate in class discussions, share their ideas and knowledge, and ask questions and receive meaningful answers. Of the design elements, the group work component took most of the in-class time but provided these opportunities best. At least two-thirds of the students said they were actively engaged during the group work, although many found the group-work questions harder or too hard. These findings suggest that overall a clear majority of students judged their experiences with the in-class group work as beneficial to their learning.

Understanding the reason for the decreased engagement in group work from the midway to the end of the course needs further exploration through more in-depth qualitative interviews, to build on the overwhelmingly positive experiences with the group work components during the first half of the course.

Compared to the group work component, the data suggest that students judged their engagement with the homework component far less favourably. Students overwhelmingly did not take up the learning opportunities provided by the homework component. Possible explanations might be the following: firstly, the sheer number of suggested textbook problems might have been a demotivating deterrent rather than an opportunity and, secondly, compared to the in-class group work on problems, where the instructor and peers were available for support, the homework component left students on their own to deal with the problems. Considering how students judged the level of course content difficulty (see Table 2), being left on their own to approach many problems might explain their reluctance to engage with the homework component. Considering that almost 8 in 10 students found the workload for the course heavy or very heavy compared to other courses (see Table 2), students who might have found the homework problems a good opportunity to practice and deepen their understanding still may have been reluctant to try the homework problems.

\section{Discussion}

One of the special features of this study compared to other studies on flipped classroom design in teaching post-secondary chemistry classes is that the participants are non-chemistry major students, for typically half of whom this course is the terminating chemistry course in their degree program. Looking at students' judgments on the overall flipped classroom design, the following picture emerges. Most students felt they had adjusted to the flipped classroom design halfway through the course and, compared to traditional lecture-style teaching, they reported feeling more in control of their learning and more comfortable asking questions and initiating discussions. About 8 out of 10 students, judged their experiences with the course design overall as a high quality learning experience in accordance with university course evaluation standards in terms of opportunities for students to participate in class discussions, share their ideas and knowledge, and ask questions and receive meaningful answers. From the perspective of the student majority, all flipped classroom design components were considered a good use of their time or valuable or effective for their learning of organic chemistry. Particularly the 
group work component and the review and preview lectures were considered by about $66 \%$ and $75 \%$ of the students, respectively, as valuable and effective in their learning of organic chemistry.

This overall positive finding of a flipped classroom design use for non-chemistry major students aligns with the findings of a similar group of study participants (Christiansen, 2014; Rein \& Brookes, 2015). Like the findings in the literature (Rein \& Brookes, 2015), students preferred watching videos over having a lecture because the videos provided greater flexibility of learning compared to a traditional lecture-style teaching approach (Smith, 2013; Weaver \& Sturtevant, 2015). This study "fine tunes" the finding that students might prefer the flexible video lecture over lecture-style teaching per $s e$, but that their judgment is relative to the quantity and placement of the lecture-style teaching. In this study, a clear majority of students judged the in-class short review and preview lectures as the most beneficial design component of the course, significantly better than the video component. As mentioned above, compared to an only-in-class-lecture experience, these lectures were characterized as relatively brief and they either reviewed material that students were to some degree already familiar or provided an overview of upcoming new material.

The overall findings of this study - and other studies involving non-chemistry majors - must be seen in the context that all students found the course content (very) difficult and about $60 \%$ of the students found the course pace fast or too fast. Content quantity and learning pace are contextual parameters which must work within the course design for non-chemistry majors. Course workload, while directly influenced by content and pace quality, is also influenced by course design. The study findings that the majority of students judged the course workload as (very) heavy aligns with the findings of other studies on flipped classrooms, regardless of whether study participants were nonchemistry majors (Shattuck, 2016; Smith, 2013). While students may find that most or all their courses have a heavy workload, our findings raise the question of whether judgments of "workload" have a perceptual rather than factual aspect having more to do with the number and newness of components in a flipped classroom design. In addition, time management is part of a major component of learning course content in a flipped classroom design that some studies report might be perceived as increased workload (Reid, 2016).

The core feature of any flipped classroom design is that in-class traditional lecture-only or lecture-dominant activity is replaced with activities that consider that students already have a lecturestyle exposure to the content prior to coming to class in which they were scheduled to (further) learn about that very content. Some form of problem-based group or peer-to-peer work is commonly used for such activity (Christiansen, 2014; Eichler \& Peeples, 2016; Fautch, 2015; Weaver \& Sturtevant, 2015). Weaver and Sturtevant (2015) found that, when asked, most students in flipped chemistry classrooms appreciate and prefer some form of peer-to-peer learning activity.

Additionally, Naibert et al. (2020) recently compared flipped general chemistry courses in five American institutions and found that the student engagement in watching videos varied depending on the structure (face-to-face) of the lecture periods. It should be noted that there is some heterogeneity in the course component designs such as different video lengths, numbers of videos to watch, how information was presented in the videos, and whether grade incentives were given for watching the videos. However, one of the conclusions drawn from their study was that students were more likely to 
watch the videos if they must participate in group work during the lecture periods (irrespective of grade incentives). Therefore, this synergistic relationship of watching video resources and participation in group work are mutually beneficial in design.

Our study suggests that using a problem-based peer-to-peer activity as a core in-class activity in a flipped classroom design needs some important distinctions. At the end of the course, about twothirds of the students in our study found the opportunity to work with other students beneficial, while only about one-half of the students found the group work activity a good use of their time. This suggests that several students drew a distinction between peer work and group work activity, which in turn suggests that the qualities of the peer-to-peer activity beyond working with peers needs to be considered in the design and future studies need to be designed with this distinction in mind. Casselman et al. (2020) also found that when class time was limited to 90 minutes, students did not demonstrate additional skills-based performance gains after collaborative group work. Using Hogan's (1999) theory of knowledge construction, the authors cite the limitations of a short interaction period with instructor and peers might be attributed to the minimal effect on skills-based performance compared to only asynchronous pre-lecture online learning. Therefore, the content design and duration of the group work activity should be considered. The findings of Casselman et al. (2020) contrast with what our students perceived as beneficial to them because a majority preferred to have two 75-minute lecture periods/week or three 50-minute lecture periods/week. We hypothesize that a shorter lecture period requires more frequent preparation by the students; however, this would be at a lower cognitive load for each lecture period, and therefore, more manageable for keeping up with course content.

\section{Conclusion}

This study contributes to the growing research on the impact of flipped classroom designs in postsecondary chemistry courses for students and on the small contingent of studies focusing on nonchemistry majors. The findings of the study generally support the findings of those studies; however, this study suggests the need for a more nuanced approach in future studies when inquiring into (nonchemistry major) students' judgment about their experiences with a flipped classroom design. These findings suggest the need for qualitative research studies to better understand the quality of students' experiences with flipped classroom designs and the different design components, considering that certain design components seem to have to be taken up more readily by students than others.

Qualitatively oriented studies could also provide a better understanding of the mechanism by which the in-class activities are impacting students' learning and students' judgment about their learning.

\section{Acknowledgements}

The authors would like to thank the students in CHEM 1320 who were willing to participate in the study as well as the University of Manitoba Faculty of Science for providing funding to support this research. 
This paper is dedicated to the memory of our colleague Dr. Philip G. Hultin, who was a dedicated and inspirational professor of organic chemistry at the University of Manitoba. 


\section{References}

Aspden, L., \& Helm, P. (2006). Making the connection in a blended learning environment. Educational Media International, 41(3), 245-252. https://doi.org/10.1080/09523980410001680851

Bernard, P., Broś, P., \& Migdał-Mikuli, A. (2017). Influence of blended learning on outcomes of students attending a general chemistry course: Summary of a five-year-long study. Chemistry Education Research and Practice, 18(4), 682-690. https://doi.org/10.1039/C7RP00040E

Casselman, M. D., Atit, K., Henbest, G., Guregyan, C., Mortezaei, K., \& Eichler, J. (2020). Dissecting the flipped classroom: Using a randomized control trial experiment to determine when student learning occurs. Journal of Chemical Education, 97(1), 27-35. https://doi.org/10.1021/acs.jchemed.9b00767

Chase, A., Pakhira, D., \& Stains, M. (2013). Implementing process-oriented, guided-inquiry learning for the first time: Adaptations and short-term impacts on students' attitude and performance. Journal of Chemical Education, 90(4), 409-416. https://doi.org/10.1021/ed300181t

Christiansen, M. A. (2014). Inverted teaching: Applying a new pedagogy to a university organic chemistry class. Journal of Chemical Education, 91(11), 1845-1850. https://doi.org/10.1021/ed400530z

Cohen, L., Manion, L., \& Morrison, K. (2011). Research methods in education (11th ed.). Routledge.

Cooner, T. S. (2010). Creating opportunities for students in large cohorts to reflect in and on practice: Lessons learnt from a formative evaluation of students' experiences of a technology-enhanced blended learning design. British Journal of Educational Technology, 41(2), 271-286. https://doi.org/10.1111/j.1467-8535.2009.00933.x

Donnelly, R. (2010). Harmonizing technology with interaction in blended problem-based learning. Computers and Education, 54(2), 350-359. https://doi.org/10.1016/j.compedu.2009.08.012

Driscoll, M. (2002). Blended learning: Let's get beyond the hype. E-Learning, 3(3), 54.

Eichler, J. F., \& Peeples, J. (2016). Flipped classroom modules for large enrollment general chemistry courses: a low barrier approach to increase active learning and improve student grades. Chemistry Education Research and Practice, 17(1), 197-208. https://doi.org/10.1039/C5RP00159E

Fautch, J. M. (2015). The flipped classroom for teaching organic chemistry in small classes: Is it effective? Chemistry Education Research and Practice, 16(1), 179-186. https://doi.org/10.1039/C4RP00230J

Flynn, A. B. (2015). Structure and evaluation of flipped chemistry courses: Organic \& spectroscopy, large and small, first to third year, English and French. Chemistry Education Research and Practice, 16(2), 198-211. https://doi.org/10.1039/C4RP00224E 
Freeman, S., Eddy, S. L., McDonough, M., Smith, M. K., Okoroafor, N., Jordt, H., \& Wenderoth, M. P. (2014). Active learning increases student performance in science, engineering, and mathematics. Proceedings of the National Academy of Sciences, 111(23), 8410-8415. https://doi.org/10.1073/pnas.1319030111

Garrison, R., \& Vaughan, N. (2013). Institutional change and leadership associated with blended learning innovation: Two case studies. The Internet and Higher Education, 18, $24-28$. https://doi.org/10.1016/j.iheduc.2012.09.001

Ginns, P., \& Ellis, R. A. (2009). Evaluating the quality of e-learning at the degree level in the student experience of blended learning. British Journal of Educational Technology, 40(4), 652-663. https://doi.org/10.1111/j.1467-8535.2008.00861.x

He, W., Holton, A., Farkas, G., \& Warschauer, M. (2016). The effects of flipped instruction on out-ofclass study time, exam performance, and student perceptions. Learning and Instruction, 45, 61-71. https://doi.org/10.1016/j.learninstruc.2016.07.001

Hemraj-Benny, T., \& Beckford, I. (2014). Cooperative and inquiry-based learning utilizing art-related topics: Teaching chemistry to community college nonscience majors. Journal of Chemical Education, 91(10), 1618-1622. https://doi.org/10.1021/ed400533r

Hernández-Nanclares, N., \& Pérez-Rodríguez, M. (2016). Students' satisfaction with a blended instructional design: The potential of "flipped classroom" in higher education. Journal of Interactive Media in Education, 2016(4), p. 12. http://dx.doi.org/10.5334/jime.397

Hibbard, L., Sung, S., \& Wells, B. (2016). Examining the effectiveness of a semi-self-paced flipped learning format in a college general chemistry sequence. Journal of Chemical Education, 93(1), 24-30. https://doi.org/10.1021/acs.jchemed.5b00592

Hogan, K. (1999). Thinking aloud together: A test of an intervention to foster students' collaborative scientific reasoning. Journal of Research in Science Technology, 36(10), 1085-1109.

Holley, D., \& Oliver, M. (2010). Student engagement and blended learning: Portraits of risk. Computers and Education, 54(3), 693-700. https://doi.org/10.1016/j.compedu.2009.08.035

Hwang, A., \& Arbaugh, J. B. (2009). Seeking feedback in blended learning: Competitive versus cooperative student attitudes and their links to learning outcome. Journal of Computer Assisted Learning, 25(3), 280-293. https://doi.org/10.1111/j.1365-2729.2009.00311.x

Kirik, O. T., \& Boz, Y. (2012). Cooperative learning instruction for conceptual change in the concepts of chemical kinetics. Chemistry Education Research and Practice, 13(3), 221-236. https://doi.org/10.1039/c1rp90072b

Lancaster, J. W., Wong, A., \& Roberts, S. J. (2012). “Tech” versus “talk”: A comparison study of two different lecture styles within a Master of Science nurse practitioner course. Nurse Education Today, 32(5). https://doi.org/10.1016/j.nedt.2011.09.018 
Lancaster, S. (2013). The flipped lecture. New Directions, 9(1), 28-32.

https://doi.org/10.11120/ndir.2013.00010

Lenczewski, M. S. (2016). Scaffolded semi-flipped general chemistry designed to support rural students' learning. Journal of Chemical Education, 93(12), 1999-2003.

https://doi.org/10.1021/acs.jchemed.6b00320

Lopez-Perez, M. V., Perez-Lopez, M. C., \& Rodriguez-Ariza, L. (2011). Blended learning in higher education: Students' perceptions and their relation to outcomes. Computers \& Education, 56(3), 818-826. https://doi.org/10.1016/j.compedu.2010.10.023

Lyon, D. C., \& Lagowski, J. J. (2008). Effectiveness of facilitating small-group learning in large lecture classes: A general chemistry case study. Journal of Chemical Education, 85(11), 1571-1576. https://doi.org/10.1021/ed085p1571

Lyons, T., \& Evans, M. M. (2013). Blended learning to increase student satisfaction: An exploratory study. Internet Reference Services Quarterly, 18(1), 43-53.

https://doi.org/10.1080/10875301.2013.800626

McNally, B., Chipperfield, J., Dorsett, P., Del Fabbro, L., Frommolt, V., Goetz, S., Lewohl, J., Molineux, M., Pearson, A., Reddan, G., Roiko, A., \& Rung, A. (2017). Flipped classroom experiences: Student preferences and flip strategy in a higher education context. Higher Education, 73(2), 281298. https://doi.org/10.1007/s10734-016-0014-z

Mooring, S. R., Mitchell, C. E., \& Burrows, N. L. (2016). Evaluation of a flipped, large-enrollment organic chemistry course on student attitude and achievement. Journal of Chemical Education, 93(12), 1972-1983. https://doi.org/10.1021/acs.jchemed.6b00367

Naibert, N., Geye, E., Philips, M., \& Barbera, J. (2020). Multicourse comparative study of the core aspects for flipped learning: Investigating in-class structure and student use of video resources. Journal of Chemical Education, 97(10), 3490-3505. https://doi.org/10.1021/acs.jchemed.0c00399

Novak, G. M. (2011). Just-in-time teaching. New Directions for Teaching and Learning, 128, 63-73. https://doi.org/10.1002/tl

Oliver-Hoyo, M. T., \& Allen, D. (2005). Attitudinal effects of a student-centered active learning environment. Journal of Chemical Education, 82(6), 944. https://doi.org/10.1021/ed082p944

Owston, R., York, D., \& Murtha, S. (2013). Student perceptions and achievement in a university blended learning strategic initiative. Internet and Higher Education, 18, 38-46.

https://doi.org/10.1016/j.iheduc.2012.12.003

Palincsar, A. S. (1998). Social constructivist perspectives on teaching and learning. Annual Review of Psychology, 49(1), 345-375. https://doi.org/10.1146/annurev.psych.49.1.345 
Rau, M. A., Kennedy, K., Oxtoby, L., Bollom, M., \& Moore, J. W. (2017). Unpacking “active learning”: A combination of flipped classroom and collaboration support is more effective but collaboration support alone is not. Journal of Chemical Education, 94(10), 1406-1414.

https://doi.org/10.1021/acs.jchemed.7b00240

Reid, S. A. (2016). A flipped classroom redesign in general chemistry. Chemistry Education Research and Practice, 17(4), 914-922. https://doi.org/10.1039/C6RP00129G

Reidsema, C., Hadgraft, R., \& Kavanagh, L. (2017). Introduction to the flipped classroom. In C. Reidsema, L. Kavanagh, R. Hadgraft, \& N. Smith (Eds.), The flipped classroom: Practice and practices in higher education (pp. 3-14). Springer Nature.

Reidsema, C., Kavanagh, L., Hadgraft, R., \& Smith, N. (Eds.). (2017). The flipped classroom: Practice and practices in higher education. Springer Nature.

Rein, K. S., \& Brookes, D. T. (2015). Student response to a partial inversion of an organic chemistry course for non-chemistry majors. Journal of Chemical Education, 92(5), 797-802. https://doi.org/10.1021/ed500537b

Rossi, R. D. (2015). Confchem conference on flipped classroom: Improving student engagement in organic chemistry using the inverted classroom model. Journal of Chemical Education, 92(9), 1577-1579. https://doi.org/10.1021/ed500899e

Ryan, M. D., \& Reid, S. A. (2016). Impact of the flipped classroom on student performance and retention: A parallel controlled study in general chemistry. Journal of Chemical Education, 93(1), 13-23. https://doi.org/10.1021/acs.jchemed.5b00717

Seery, M. K. (2015). Flipped learning in higher education chemistry: Emerging trends and potential directions. Chemistry Education Research and Practice, 16(4), 758-768. https://doi.org/10.1039/C5RP00136F

Shattuck, J. C. (2016). A Parallel controlled study of the effectiveness of a partially flipped organic chemistry course on student performance, perceptions, and course completion. Journal of Chemical Education, 93(12), 1984-1992. https://doi.org/10.1021/acs.jchemed.6b00393

Shea, P., \& Bidjerano, T. (2010). Learning presence: Towards a theory of self-efficacy, self-regulation, and the development of a communities of inquiry in online and blended learning environments. Computers and Education, 55(4), 1721-731. https://doi.org/10.1016/j.compedu.2010.07.017

Slunt, K. M., \& Giancarlo, L. C. (2004). Student-centered learning: A comparison of two different methods of instruction. Journal of Chemical Education, 81(7), 985. https://doi.org/10.1021/ed081p985

Smith, J. D. (2013). Student attitudes toward flipping the general chemistry classroom. Chemistry Education Research and Practice, 14(4), 607-614. https://doi.org/10.1039/C3RP00083D 
Smyth, S., Houghton, C., Cooney, A., \& Casey, D. (2012). Students' experiences of blended learning across a range of postgraduate programmes. Nurse Education Today, 32(4), 464-468. https://doi.org/10.1016/j.nedt.2011.05.014

Snodgrass, S. (2011). Wiki activities in blended learning for health professional students: Enhancing critical thinking and clinical reasoning skills. Australasian Journal of Educational Technology, 27(4), 563-580. https://doi.org/10.1108/08858620810850227

Snodin, N. S. (2013). The effects of blended learning with a CMS on the development of autonomous learning: A case study of different degrees of autonomy achieved by individual learners. Computers and Education, 61(1), 209-216. https://doi.org/10.1016/j.compedu.2012.10.004

Sweller, J. (1994). Cognitive load theory, learning difficulty, and instructional design. Learning and Instruction, 4, 295-312. https://doi.org/10.1016/0959-4752(94)90003-5

Trogden, B. G. (2015). Confchem conference on flipped classroom: Reclaiming face time - How an organic chemistry flipped classroom provided access to increased guided engagement. Journal of Chemical Education, 92(9), 1570-1571. https://doi.org/10.1021/ed500914w

Warfa, A.-R. M. (2016). Using cooperative learning to teach chemistry: A meta-analytic review. Journal of Chemical Education, 93(2), 248-255. https://doi.org/10.1021/acs.jchemed.5b00608

Weaver, G. C., \& Sturtevant, H. G. (2015). Design, implementation, and evaluation of a flipped format general chemistry course. Journal of Chemical Education, 92(9), 1437-1448. https://doi.org/10.1021/acs.jchemed.5b00316

Woltering, V., Herrler, A., Spitzer, K., \& Spreckelsen, C. (2009). Blended learning positively affects students' satisfaction and the role of the tutor in the problem-based learning process: Results of a mixed-method evaluation. Advances in Health Sciences Education, 14(5), 725-738. https://doi.org/10.1007/s10459-009-9154-6

Wu, J.-H., Tennyson, R. D., \& Hsia, T.-L. (2010). A study of student satisfaction in a blended e-learning system environment. Computers \& Education, 55(1), 155-164. https://doi.org/10.1016/j.compedu.2009.12.012 


\section{Authors}

Horace Luong is a senior instructor in the Department of Chemistry at the University of Manitoba, Canada. His research interests are in developing novel synthetic organic chemistry experiments for undergraduate students with a focus towards green chemistry. Email: Horace.Luong@umanitoba.ca.

Thomas Falkenberg, Professor, Faculty of Education, University of Manitoba, Canada and the editor or co-editor of a number of books on teacher education and education for sustainable well-being. Thomas is the current Chair of the Editorial Board of the ESWB Press of the University of Manitoba (www.ESWB-Press.org). For more details, see his professional website: http://ThomasFalkenberg.ca. Email: Thomas.Falkenberg@umanitoba.ca.

Mahdi (Matt) Rahimian, Academic Integrity Coordinator at Queen's University in Ontario, Canada.. Matt has worked in more than fourteen post-secondary institutions in Canada and abroad. His areas of interest include post-secondary education, international education, second/additional language learning, and research methodology in education. Email: m.rahimian@queensu.ca; rahimian333@yahoo.com.

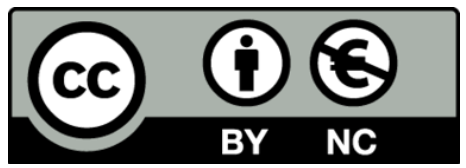

This work is licensed under a Creative Commons Attribution-NonCommercial CCBY-NC 4.0 International license. 